International Journal of Social Science and Economic Research

ISSN: 2455-8834

Volume:05, Issue:08 "August 2020"

\title{
EFFECT OF AGE ON STYLES OF CLOTHING PREFERRED BY WOMEN IN CHANDIGARH
}

\author{
Gunjan Chawla ${ }^{1}$, Rita Kant ${ }^{2}$ \\ ${ }^{1}$ M.Sc. Fashion and Lifestyle Technology, Panjab University, Chandigarh \\ ${ }^{2}$ Fashion and Lifestyle Technology, Panjab University, Chandigarh
}

DOI: 10.46609/IJSSER.2020.v05i08.008 URL: https://doi.org/10.46609/IJSSER.2020.v05i08.008

\begin{abstract}
Clothing is an important basic requirement for everyone. It is a way of protecting the human body from extreme weather conditions and hostile environment conditions. Clothing is a style in which one represents oneself and expresses one's feelings and personality type. The present research was undertaken to study the Effect of Age on Styles of Clothing Preferred by Women in Chandigarh. A survey was conducted for which a questionnaire was prepared and used as an interview schedule to collect data. The sample of the study included girls and women between the ages 25 to 45 years. The analysis of data showed that younger women in the age group ranging between 25 to 30 years in comparison to older women in the age group ranging from 31 to 45 years feel that "Fashion Magazines" do not influence their Clothing Choices. Also, women in the age group of 25 to 30 years and 31 to 35 years feel that their Clothing Choices are not affected by "Looking at What Others Wear". Further, women of all age groups were neutral towards "Movies" influencing their Clothing Choices. It was further seen that women of age group of 25 to 30 years, 31 to 35 years and 36 to 40 years like to wear "Western Casuals", whereas Older Women in the age group of 41 to 45 years like to wear "Indian Casuals". It was also seen that women of age group 25 to 30 years, 31 to 35 years and 36 to 40 years were neutral towards the preference for "Circular Silhouettes" but, women of age group 41 to 45 years prefer wearing "Circular Silhouettes". Also, "A-Line Silhouettes" were preferred the most by the women of age group 25 to 30 years, 31 to 35 years and 41 to 45 years but women of age group 36 to 40 years said that they prefer "Circular Silhouettes" to "A-Line Silhouettes". Thus on the whole this research helped to conclude that women of different age groups feel differently about what and who inspires them to wear a certain style of clothing. Older women like to wear more of Indian style casual clothing and younger women prefer more of Western style casual clothing. Also there are distinct choices in preference for silhouettes as well. Younger women prefer ALine silhouettes and older women like Circular Silhouettes. This could be because of the change
\end{abstract}




\section{International Journal of Social Science and Economic Research}

ISSN: $2455-8834$

Volume:05, Issue:08 "August 2020"

in body type of women as they grow older. Circular silhouettes seem to keep the actual body type under wraps; hence the preference for the same. Findings of this study can be useful for those involved in the business of fashion clothing.

Keywords: woman, Age, Clothes , Fashion,Choice

\section{Introduction}

Food, Clothing and Shelter are the most important basic requirements for everyone's life. Clothing was first invented by the people of Neanderthal, from about 200,000 B.C.E to about 30,000 B.C.E. The first assembled piece of clothing was a "Tunic". It was considered as a method of protecting human body against extreme weather conditions. Material used for clothing has evolved from use of leaves to use of animal skin, leather and now a vast variety of fabrics.

Every individual wears a typical costume that describes culture and attitude of that person and sometimes even the religion and caste he or she belongs to. "Costume" is derived from a Latin word "consuetude" which means a complete set of outer garments including ornaments and hairstyles. In early times, it was seen that people of who held a higher status or belonged to a higher class wore costumes that were different from those worn by people from lower class or those who did not enjoy a high status in society. Clothing takes the form of symbols used by individuals as a tool for social interaction. Thus thinkers have given there are four theories of Clothing, which are Modesty Theory, Immodesty Theory, Adornment Theory and Protection Theory.

Clothes speak about one's personality and behavior. They make one look elegant and communicate about a person. Clothing is a style in which one represents oneself and expresses one's feelings and personality type. Everyone has a different style and different taste of clothing. In present times in the Indian context clothing is seen as Western wear, Ethnic or Traditional wear and Indo-Western Wear. Western wear is a category of men's and women's clothing which derives its unique style from the clothes worn in the 19th century Wild West. Western wear can be very informal, with a t-shirt and blue jeans forming a basic ensemble, or it may consist of tailored formal garments like tops, dresses, jackets, sweatshirts, Single shoulder dresses, off shoulder tops, cold shoulder tops and other with western accents. Ethnic wear dresses are the ones which show the values, attitudes and the behavior of people towards their culture and religion. These are the dresses which are normally worn on special occasions. The special occasion ethnic wear dresses are much heavier than the normal day to day wear ethnic/traditional dresses. In the present day, there are very less number of people who like to wear these dresses. In the present times, many women are seen wearing innovative type of clothing that is a combination of ethnic and western wear. This combining of ethnic wear and western wear, is 


\section{International Journal of Social Science and Economic Research}

ISSN: $2455-8834$

Volume:05, Issue:08 "August 2020"

known as Fusion wear of popularly called Indo-Western wear.

\section{Review of Literature}

Klepp, $\mathbf{G}$ et al (2005) in their study 'Reading fashion as age: teenage girls, and grown women's accounts of clothing as body and social status" studied that the relationship between clothes and age have always been very important to differentiate people according to age. Mainly people are expected to dress according to their age, if they are found not dressed accordingly the society imposes sanctions against wearing the costume of another age.

Luniya, V et al (2007) in their study "effect of clothing on physical and mental wellbeing of old aged women" founded that body structure of old ladies becomes changed i.e. change in their abdomen, shoulder, bust, waist etc. which causes many fitting and wearing problems and in turn hurt their psychological needs. By considering all these points, the three basic garments, wore by these ladies, were suggested to be altered and then tested on them.

Twigg, J (2010) in her study "how does vogue negotiate age? Fashion, the body and the older women" focused on role played by clothing and fashion in the constitution of age, exploring the changing ways in which aging is experienced, understood and imagined in modern culture through an analysis of the responses of UK Vogue. This shows that older women in Vogue only feature sporadically and predominantly in ways that dilute or efface their age.

Parveen, $\mathbf{C}$ et al (2012) in their study "influence of collective self-esteem on fashion clothing involvement among Indian women" examined the influence of collective self-esteem, age, income, marital status and education of Indian women predicting their fashion clothing involvement. The data was collected by contacting women in their offices, colleges and malls in five different cities of India. The findings reveal that fashion clothing involvement of Indian women is influenced by age, importance to identity and public-esteem.

Twigg, J (2015) in her study "Clothing, identity, embodiment and age" explored the links between clothing and the social expression of age, looking in particular at the tradition of age ordering in dress. It is said that there is an evidence that this ordering has been eroded or has changed in recent years. The author also reviews arguments for this erosion and also explores the significance of the baby boomer cohort and their adoption of Casual dress.

\section{Methodology}

Based on the researcher's observation and text readings, the problem to be studied was identified and worded accurately. A close perusal of literature helped in framing the objectives of the study. This followed developing an instrument and its pretesting on a given population. 
The questionnaire was based on the objectives of the study. The first section of the questionnaire was about the general information of the respondent like, name, age, occupation, education, family, etc. These questions were framed to ascertain the socio-economic background of the respondents. The second section of the questionnaire was related to the clothing preferences of the respondents with respect to their choice for Style of dress preferred to be worn by respondents on different occasions and seasons based on their occupation and silhouette of dress and style-lines in the dress based on the height and weight of respondents.

Sample for the study was then identified and by Random Sampling Technique 100 respondents were approached to fill the questionnaire. The sample of the study included women ranging from 25 years to 45 years of age. They were approached in the main shopping hubs i.e. Sector-17 Shopping Plaza, Sector-22 Market and Elante Mall of Chandigarh City. The researcher randomly picked the respondents in these areas. 25 respondents from each of these areas were requested to fill up the questionnaire. A sample of another 25 respondents was approached when they were partying in a kitty group in an identified hotel. This was a preset meeting. The researcher noted down observations she made while filling answers to the questions. The data thus collected was then coded and tabulated in Microsoft Excel for further analysis. Discussion of the results helped arrive at precise conclusions.

\section{Results and Discussion}

The data was analyzed and interpreted on order to make the findings useful for fashion retail businesses that want to establish themselves or want to accelerate their sales.

Table 1: Factors that Affect Clothing Choices of Women

\begin{tabular}{|l|l|c|c|}
\hline Factors & \multicolumn{1}{|c|}{$\begin{array}{c}\text { Degree of } \\
\text { Preference }\end{array}$} & Frequency & Percent \\
\hline \multirow{4}{*}{$\begin{array}{l}\text { Fashion } \\
\text { Magazines }\end{array}$} & Strongly disagree & 3 & 3.0 \\
\cline { 2 - 4 } & Disagree & 6 & 6.0 \\
\cline { 2 - 4 } & Neutral & 46 & 46.0 \\
\cline { 2 - 4 } & Agree & 34 & 34.0 \\
\cline { 2 - 4 } & Strongly agree & 11 & 11.0 \\
\cline { 2 - 4 } & Total & $\mathbf{1 0 0}$ & $\mathbf{1 0 0 . 0}$ \\
\hline \multirow{3}{*}{$\begin{array}{l}\text { Friends } \\
\text { Famd }\end{array}$} & Strongly disagree & 3 & 3.0 \\
\cline { 2 - 4 } & Disagree & 2 & 2.0 \\
\cline { 2 - 4 } & Neutral & 32 & 32.0 \\
\cline { 2 - 4 } & Agree & 25 & 25.0 \\
\cline { 2 - 4 } & Strongly agree & 38 & 38.0 \\
\hline
\end{tabular}


International Journal of Social Science and Economic Research

ISSN: 2455-8834

Volume:05, Issue:08 "August 2020"

\begin{tabular}{|c|c|c|c|}
\hline & Total & 100 & 100.0 \\
\hline \multirow{6}{*}{$\begin{array}{l}\text { Look at } \\
\text { What } \\
\text { Other's } \\
\text { Wear }\end{array}$} & Strongly disagree & 30 & 30.0 \\
\hline & Disagree & 8 & 8.0 \\
\hline & Neutral & 30 & 30.0 \\
\hline & Agree & 15 & 15.0 \\
\hline & Strongly agree & 17 & 17.0 \\
\hline & Total & 100 & 100.0 \\
\hline \multirow{6}{*}{$\begin{array}{l}\text { Designer's } \\
\text { Collection }\end{array}$} & Strongly disagree & 13 & 13.0 \\
\hline & Disagree & 5 & 5.0 \\
\hline & Neutral & 35 & 35.0 \\
\hline & Agree & 28 & 28.0 \\
\hline & Strongly agree & 19 & 19.0 \\
\hline & Total & 100 & 100.0 \\
\hline \multirow{6}{*}{ Movies } & Strongly disagree & 13 & 13.0 \\
\hline & Disagree & 12 & 12.0 \\
\hline & Neutral & 48 & 48.0 \\
\hline & Agree & 22 & 22.0 \\
\hline & Strongly agree & 5 & 5.0 \\
\hline & Total & 100 & 100.0 \\
\hline \multirow{6}{*}{ Celebrities } & Strongly disagree & 14 & 14.0 \\
\hline & Disagree & 9 & 9.0 \\
\hline & Neutral & 52 & 52.0 \\
\hline & Agree & 16 & 16.0 \\
\hline & Strongly agree & 9 & 9.0 \\
\hline & Total & 100 & 100.0 \\
\hline
\end{tabular}




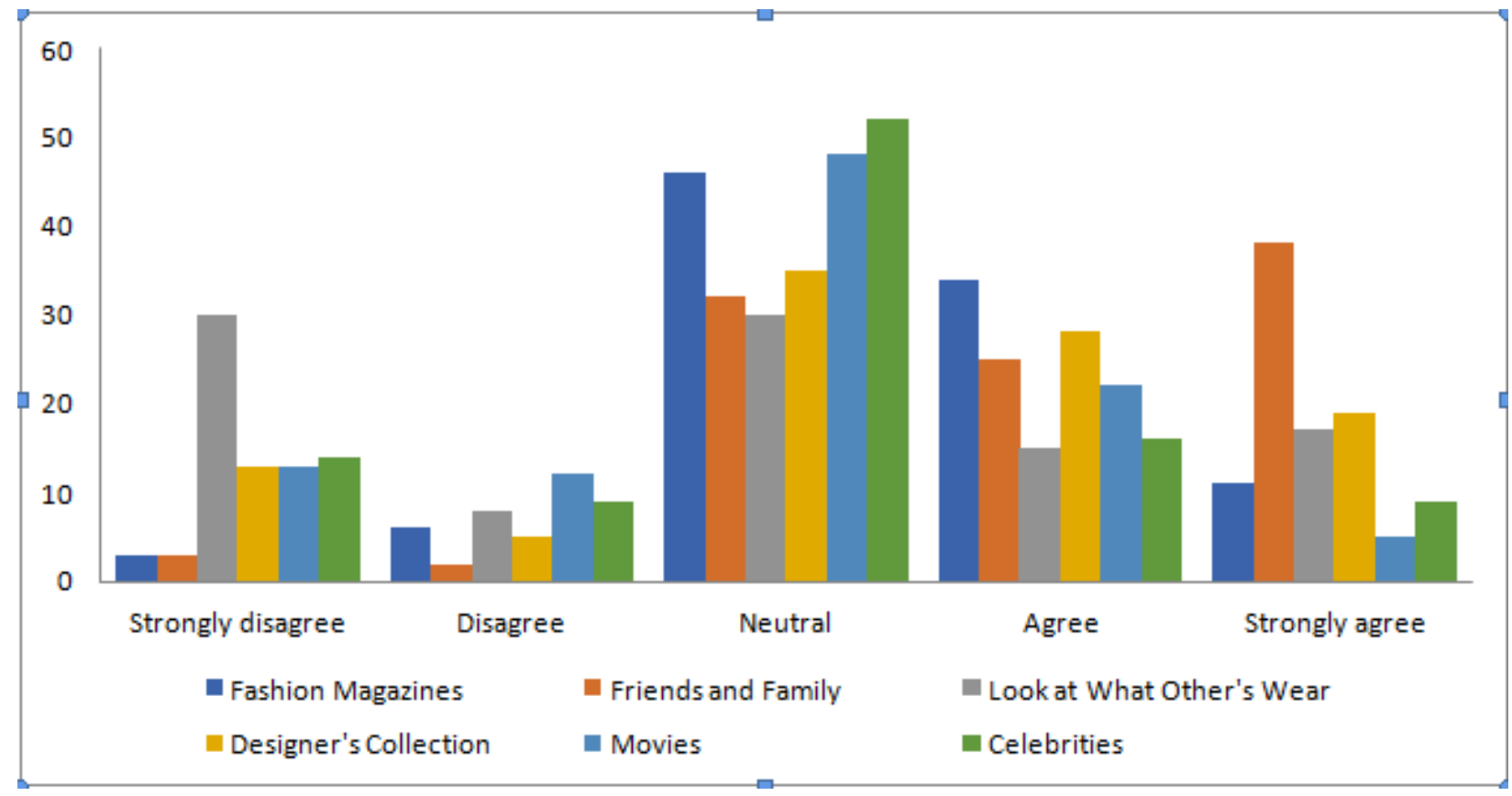

Figure1: Factors that Affect Clothing Choices of Women

\section{Analysis of Result}

It can be seen from the data above that largest percentage of respondents; 38\% Strongly Agree that they are influenced by Friends and Family while making their Clothing Choices.34\% Agree that Fashion Magazines influence them and 28\% Agree that they are influenced by Designer Collection. Factors that least influence the Clothing Choices of respondents are: Others Wear, Movies and Celebrities. These factors rank lower in the preference rank lower in the preference of respondents.

Table 2: Choice of Style of Clothing found Comfortable to Wear

\begin{tabular}{|l|l|c|c|}
\hline \multicolumn{2}{|c|}{ Choice } & Frequency & Percent \\
\hline 1. & Indian Casual & 28 & 28.0 \\
\hline 2. & Indian Traditional & 20 & 20.0 \\
\hline 3. & Western casual & 29 & 29.0 \\
\hline 4. & Western Formal & 6 & 6.0 \\
\hline 5. & Indo-Western & 17 & 17.0 \\
\hline & Total & 100 & 100.0 \\
\hline
\end{tabular}




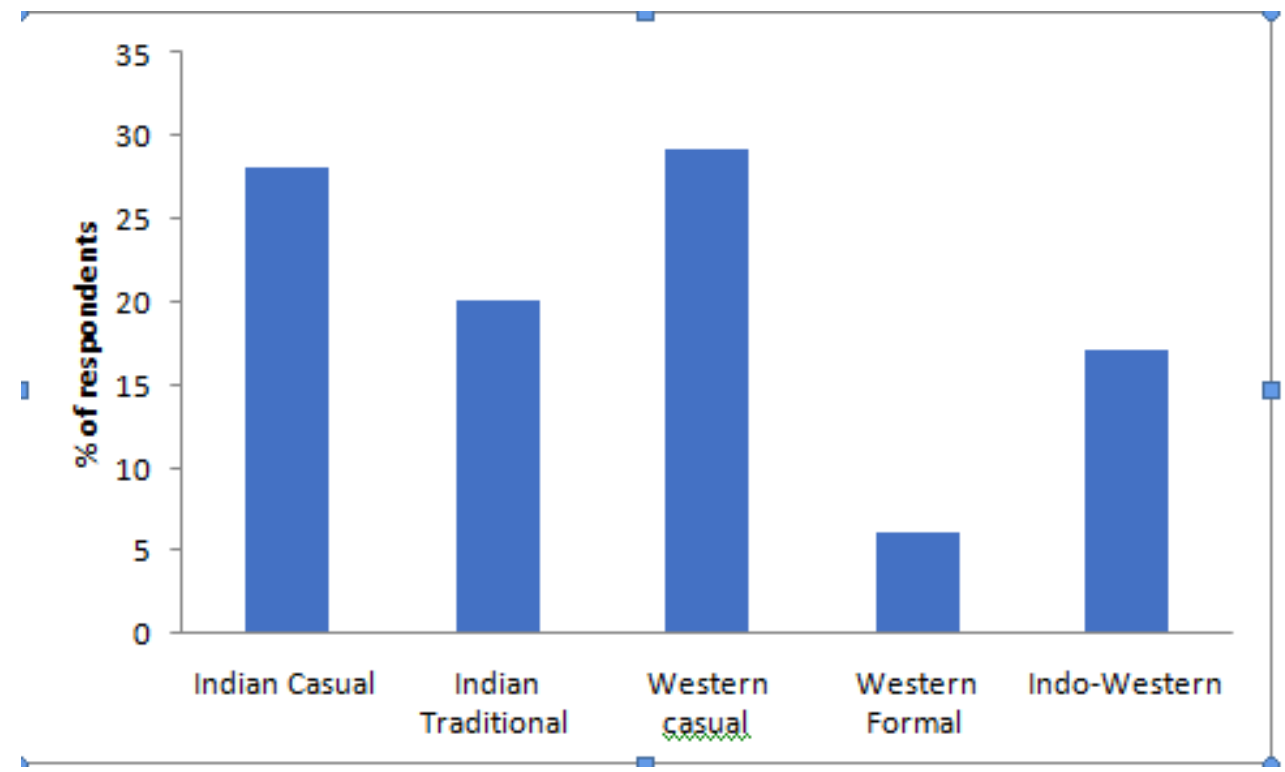

Figure 2: Choice of Style of Clothing found Comfortable to Wear

\section{Analysis of Result}

It can be seen from Table 4.8 and Figure 4.8 that while $28 \%$ respondents find Indian Casual Clothing comfortable to wear, 29\% respondents said they find Western Casual Clothing comfortable to wear. 17\% find Indo-Western Clothing comfortable. Only 6\% find Western Clothing comfortable while 20\% find Indian Traditional Clothing comfortable.

Table 3: Preference of Respondents for Silhouettes, which make them, feel Elegant and Comfortable

\begin{tabular}{|l|l|c|c|}
\hline Silhouettes & \multicolumn{1}{|c|}{ Preference } & Frequency & Percent \\
\hline Straight & $\begin{array}{l}\text { Generally not } \\
\text { preferred }\end{array}$ & 1 & 1.0 \\
\cline { 2 - 4 } & Neutral & 5 & 5.0 \\
\cline { 2 - 4 } & Preferred a little & 24 & 24.0 \\
\cline { 2 - 4 } & Preferred the most & 70 & 70.0 \\
\cline { 2 - 4 } & Total & $\mathbf{1 0 0}$ & $\mathbf{1 0 0 . 0}$ \\
\hline A-Line & $\begin{array}{l}\text { Generally not } \\
\text { preferred }\end{array}$ & 3 & 3.0 \\
\cline { 2 - 4 } & Neutral & 18 & 18.0 \\
\cline { 2 - 4 } & Preferred a little & 38 & 38.0 \\
\cline { 2 - 4 } & Preferred the most & 41 & 41.0 \\
\cline { 2 - 4 } & Total & $\mathbf{1 0 0}$ & $\mathbf{1 0 0 . 0}$ \\
\hline
\end{tabular}


International Journal of Social Science and Economic Research

ISSN: 2455-8834

Volume:05, Issue:08 "August 2020"

\begin{tabular}{|c|c|c|c|}
\hline \multirow{6}{*}{$\begin{array}{l}\text { Glass } \\
\text { Shape }\end{array}$} & Not at all preferred & 30 & 30.0 \\
\hline & $\begin{array}{l}\text { Generally not } \\
\text { preferred }\end{array}$ & 30 & 30.0 \\
\hline & Neutral & 29 & 29.0 \\
\hline & Preferred a little & 8 & 8.0 \\
\hline & Preferred the most & 3 & 3.0 \\
\hline & Total & 100 & 100.0 \\
\hline \multirow[t]{6}{*}{ Bell Shape } & Not at all preferred & 17 & 17.0 \\
\hline & $\begin{array}{l}\text { Generally not } \\
\text { preferred }\end{array}$ & 41 & 41.0 \\
\hline & Neutral & 18 & 18.0 \\
\hline & Preferred a little & 16 & 16.0 \\
\hline & Preferred the most & 8 & 8.0 \\
\hline & Total & 100 & 100.0 \\
\hline \multirow[t]{6}{*}{ Circular } & Not at all preferred & 15 & 15.0 \\
\hline & $\begin{array}{l}\text { Generally not } \\
\text { preferred }\end{array}$ & 26 & 26.0 \\
\hline & Neutral & 39 & 39.0 \\
\hline & Preferred a little & 15 & 15.0 \\
\hline & Preferred the most & 5 & 5.0 \\
\hline & Total & 100 & 100.0 \\
\hline \multirow[t]{6}{*}{ Flowy } & Not at all preferred & 8 & 8.0 \\
\hline & $\begin{array}{l}\text { Generally not } \\
\text { preferred }\end{array}$ & 14 & 14.0 \\
\hline & Neutral & 38 & 38.0 \\
\hline & Preferred a little & 26 & 26.0 \\
\hline & Preferred the most & 14 & 14.0 \\
\hline & Total & $\mathbf{1 0 0}$ & 100.0 \\
\hline
\end{tabular}




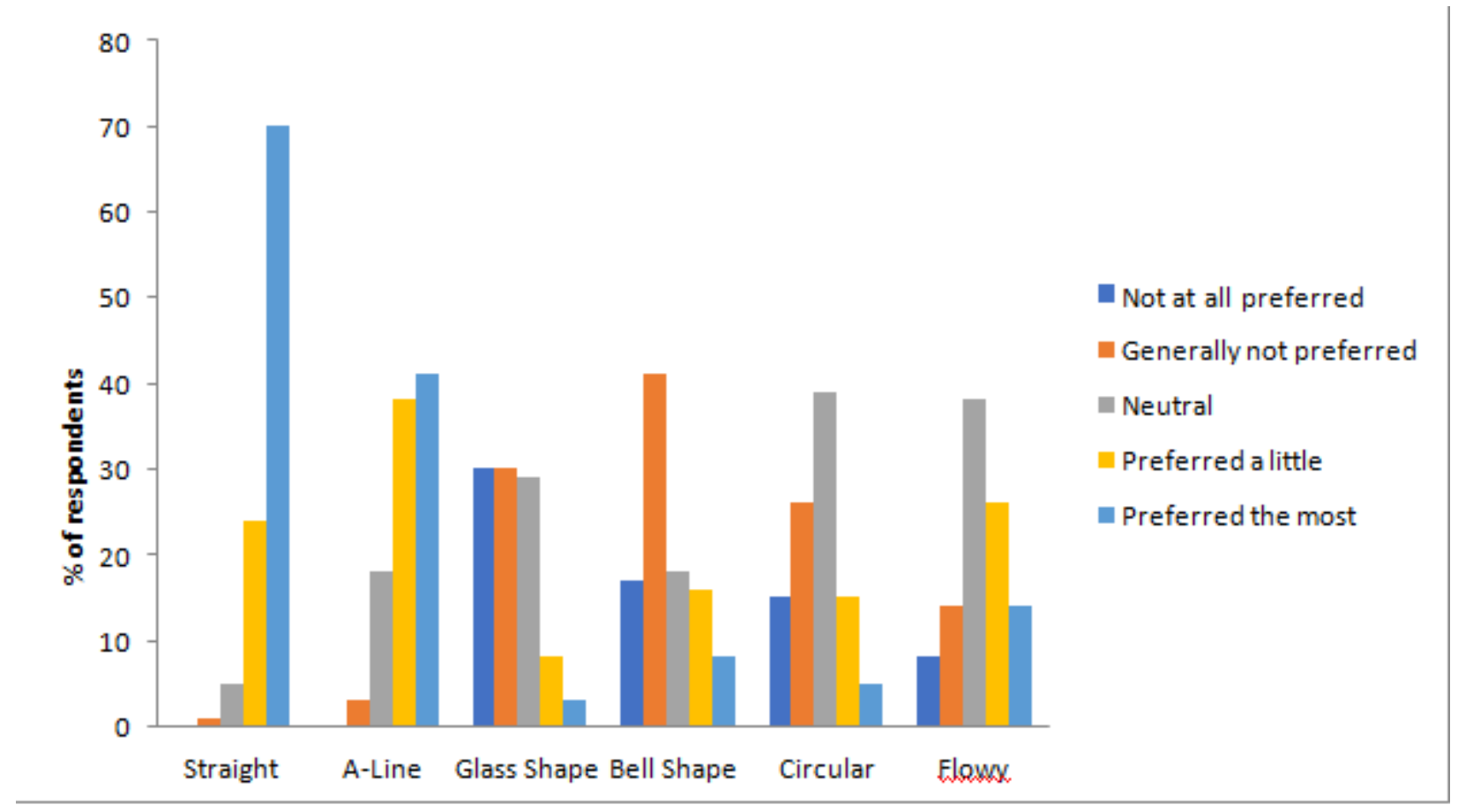

\section{Analysis of Result}

It can be seen from the data above that a larger number of respondents feel that Straight Silhouettes make them feel Elegant and Comfortable followed by respondents saying that A-Line Silhouettes made them feel Elegant and Comfortable.

The Glass Shape Silhouette and Bell Shape Silhouette are least preferred silhouettes by most of the respondents. Also, the Circular Silhouettes and Flowy Silhouettes lie between the most preferred Silhouettes and the least preferred Silhouettes. 
International Journal of Social Science and Economic Research

ISSN: 2455-8834

Volume:05, Issue:08 "August 2020"

Table 4: Relationship of Age with Effect of Fashion Magazines on Clothing Choices of Women

\begin{tabular}{|c|c|c|c|c|c|c|c|c|c|c|c|c|c|}
\hline \multirow{3}{*}{$\begin{array}{l}\text { Demographic } \\
\text { Factor } \\
\text { Age }\end{array}$} & \multirow{3}{*}{$\begin{array}{c}\text { Age } \\
\text { Groups } \\
25-30\end{array}$} & \multicolumn{12}{|c|}{ Effect of Fashion Magazines on Clothing Choices of Women } \\
\hline & & \multicolumn{2}{|c|}{$\begin{array}{c}\text { Strongly } \\
\text { Agree }\end{array}$} & \multicolumn{2}{|c|}{ Agree } & \multicolumn{2}{|c|}{ Neutral } & \multicolumn{2}{|c|}{ Disagree } & \multicolumn{2}{|c|}{$\begin{array}{l}\text { Strongly } \\
\text { Disagree }\end{array}$} & \multicolumn{2}{|c|}{ Total } \\
\hline & & 0 & $0.0 \%$ & 0 & $0.0 \%$ & 9 & $36.0 \%$ & 11 & $44.0 \%$ & 5 & $20.0 \%$ & 25 & $100.0 \%$ \\
\hline & 31-35 & 0 & $0.0 \%$ & 0 & $0.0 \%$ & 11 & $44.0 \%$ & 11 & $44.0 \%$ & 3 & $12.0 \%$ & 25 & $100.0 \%$ \\
\hline & 36-40 & 1 & $4.0 \%$ & 1 & $4.0 \%$ & 16 & $64.0 \%$ & 5 & $20.0 \%$ & 2 & $8.0 \%$ & 25 & $100.0 \%$ \\
\hline & 41-45 & 2 & $8.0 \%$ & 5 & $20.0 \%$ & 10 & $40.0 \%$ & 7 & $28.0 \%$ & 1 & $4.0 \%$ & 25 & $100.0 \%$ \\
\hline & Total & 3 & $3.0 \%$ & 6 & $6.0 \%$ & 46 & $46.0 \%$ & 34 & $34.0 \%$ & 11 & $11.0 \%$ & 100 & $100.0 \%$ \\
\hline
\end{tabular}

\begin{tabular}{|l|l|c|}
\hline \multicolumn{3}{|c|}{ Pearson Chi-Square Tests } \\
\hline \multicolumn{3}{|c|}{ Effect of Fashion Magazines on Clothing Choices of Women } \\
\hline \multirow{3}{*}{ Age } & Chi-square & 23.880 \\
\cline { 2 - 3 } & Df & 12 \\
\cline { 2 - 3 } & Sig. & $.021^{*}$ \\
\hline
\end{tabular}

*Significant at 0.05 Level

\section{Discussion of Result}

Age has a significant influence on the effect of Fashion Magazines on Clothing Choices of Women. The obtained value of Chi Square ( $\square 2)$ is 23.880, which is significant at .021 level of p value. 
International Journal of Social Science and Economic Research

ISSN: 2455-8834

Volume:05, Issue:08 "August 2020"

Table 5: Relationship of Age with Effect of What Others' Wear on Clothing Choices of Women

\begin{tabular}{|c|c|c|c|c|c|c|c|c|c|c|c|c|c|}
\hline \multirow{3}{*}{$\begin{array}{l}\text { Age } \\
\text { Age }\end{array}$} & \multirow{3}{*}{$\begin{array}{l}\text { Status } \\
25-30\end{array}$} & \multicolumn{12}{|c|}{ Effect of What Others' Wear on Clothing Choices of Women } \\
\hline & & \multicolumn{2}{|c|}{ Strongly disagree } & \multicolumn{2}{|c|}{ Disagree } & \multicolumn{2}{|c|}{ Neutral } & \multicolumn{2}{|c|}{ Agree } & \multicolumn{2}{|c|}{$\begin{array}{c}\text { Strongly } \\
\text { agree }\end{array}$} & \multicolumn{2}{|c|}{ Total } \\
\hline & & 14 & $56.0 \%$ & 3 & $12.0 \%$ & 6 & $24.0 \%$ & 0 & $0.0 \%$ & 2 & $8.0 \%$ & 25 & $100.0 \%$ \\
\hline & 31-35 & 9 & $36.0 \%$ & 2 & $8.0 \%$ & 5 & $20.0 \%$ & 2 & $8.0 \%$ & 7 & $28.0 \%$ & 25 & $100.0 \%$ \\
\hline & $36-40$ & 3 & $12.0 \%$ & 2 & $8.0 \%$ & 11 & $44.0 \%$ & 4 & $16.0 \%$ & 5 & $20.0 \%$ & 25 & $100.0 \%$ \\
\hline & 41-45 & 4 & $16.0 \%$ & 1 & $4.0 \%$ & 8 & $32.0 \%$ & 9 & $36.0 \%$ & 3 & $12.0 \%$ & 25 & $100.0 \%$ \\
\hline & Total & 30 & $30.0 \%$ & 8 & $8.0 \%$ & 30 & $30.0 \%$ & 15 & $15.0 \%$ & 17 & $17.0 \%$ & 100 & $100.0 \%$ \\
\hline
\end{tabular}

\begin{tabular}{|l|l|c|}
\hline \multicolumn{2}{|c|}{ Pearson Chi-Square Tests } \\
\hline \multirow{2}{*}{ Age } & $\begin{array}{l}\text { Effect of What Others' Wear on Clothing Choices of Women } \\
\text { square }\end{array}$ & 29.471 \\
\cline { 2 - 3 } & Df & 12 \\
\cline { 2 - 3 } & Sig. & $.003^{*}$ \\
\hline
\end{tabular}

*Significant at 0.05 Level

\section{Discussion of Result}

Age of Women has significant influence on the effect of What Others' Wear on Clothing Choices of Women. The obtained value of Chi Square ( $\square 2)$ is 29.471 , which is significant at .003 level of $p$ value. 
International Journal of Social Science and Economic Research

ISSN: 2455-8834

Volume:05, Issue:08 "August 2020"

Table 6: Relationship of Age with Effect of Movies on Clothing Choices of Women

\begin{tabular}{|c|c|c|c|c|c|c|c|c|c|c|c|c|c|}
\hline \multirow{3}{*}{\begin{tabular}{|l} 
Demographic \\
Factor
\end{tabular}} & \multirow{3}{*}{$\begin{array}{c}\begin{array}{c}\text { Age } \\
\text { Groups }\end{array} \\
25-30\end{array}$} & \multicolumn{12}{|c|}{ Preference of Movies in Clothing Choices } \\
\hline & & \multicolumn{2}{|c|}{$\begin{array}{l}\text { Strongly } \\
\text { disagree }\end{array}$} & \multicolumn{2}{|c|}{ Disagree } & \multicolumn{2}{|c|}{ Neutral } & \multicolumn{2}{|c|}{ Agree } & \multicolumn{2}{|c|}{$\begin{array}{l}\text { Strongly } \\
\text { agree }\end{array}$} & \multicolumn{2}{|c|}{ Total } \\
\hline & & 4 & $\begin{array}{c}16.0 \\
\%\end{array}$ & 2 & $8.0 \%$ & 13 & $\begin{array}{c}52.0 \\
\%\end{array}$ & 5 & $\begin{array}{c}20.0 \\
\%\end{array}$ & 1 & $\begin{array}{l}4.0 \\
\%\end{array}$ & $\begin{array}{l}2 \\
5 \\
\end{array}$ & $\begin{array}{l}100 \\
.0 \%\end{array}$ \\
\hline & $31-35$ & 2 & $8.0 \%$ & 0 & $0.0 \%$ & 18 & $\begin{array}{c}72.0 \\
\%\end{array}$ & 5 & $\begin{array}{c}20.0 \\
\%\end{array}$ & 0 & $\begin{array}{l}0.0 \\
\%\end{array}$ & $\begin{array}{l}2 \\
5\end{array}$ & $\begin{array}{l}100 \\
.0 \%\end{array}$ \\
\hline & $36-40$ & 4 & $\begin{array}{c}16.0 \\
\%\end{array}$ & 6 & $\begin{array}{c}24.0 \\
\%\end{array}$ & 10 & $\begin{array}{l}40.0 \\
\%\end{array}$ & 5 & $\begin{array}{c}20.0 \\
\%\end{array}$ & 0 & $\begin{array}{l}0.0 \\
\%\end{array}$ & $\begin{array}{l}2 \\
5\end{array}$ & $\begin{array}{l}100 \\
.0 \%\end{array}$ \\
\hline & $41-45$ & 3 & $\begin{array}{c}12.0 \\
\%\end{array}$ & 4 & $\begin{array}{c}16.0 \\
\%\end{array}$ & 7 & $\begin{array}{c}28.0 \\
\%\end{array}$ & 7 & $\begin{array}{c}28.0 \\
\%\end{array}$ & 4 & $\begin{array}{l}16 . \\
0 \%\end{array}$ & $\begin{array}{l}2 \\
5 \\
\end{array}$ & $\begin{array}{l}100 \\
.0 \%\end{array}$ \\
\hline & Total & 13 & $\begin{array}{c}13.0 \\
\%\end{array}$ & $\begin{array}{l}1 \\
2\end{array}$ & $\begin{array}{c}12.0 \\
\%\end{array}$ & 48 & $\begin{array}{c}48.0 \\
\%\end{array}$ & 22 & $\begin{array}{c}22.0 \\
\%\end{array}$ & 5 & $\begin{array}{c}5.0 \\
\%\end{array}$ & $\begin{array}{l}1 \\
0 \\
0\end{array}$ & $\begin{array}{l}100 \\
.0 \%\end{array}$ \\
\hline
\end{tabular}

\begin{tabular}{|l|l|c|}
\hline \multicolumn{3}{|c|}{ Pearson Chi-Square Tests } \\
\hline \multirow{3}{*}{ Preference of Movies in Clothing Choices } \\
\cline { 2 - 3 } & Chi-square & 22.158 \\
\cline { 2 - 3 } & Df & $.036^{*}$ \\
\cline { 2 - 3 } & Sig. & 12 \\
\hline
\end{tabular}

*Significant at 0.05 Level

\section{Discussion of Result}

Age has a significant influence on the effect of Movies on Clothing Choices of Women. The obtained value of Chi Square ( $\square 2$ ) is 22.158, which is significant at .036 level of p value.

Table 7: Relationship of Age and Style of Clothing Women like to wear.

\begin{tabular}{|c|c|c|c|c|c|c|c|c|c|c|c|c|c|}
\hline \multirow{3}{*}{$\begin{array}{l}\begin{array}{c}\text { Demographic } \\
\text { Factor }\end{array} \\
\text { Age }\end{array}$} & \multirow{3}{*}{\begin{tabular}{|l|} 
Status \\
$25-30$ \\
\end{tabular}} & \multicolumn{12}{|c|}{ Style of Clothing Women Prefer to Wear } \\
\hline & & \multicolumn{2}{|c|}{ Indian Casual } & \multicolumn{2}{|c|}{$\begin{array}{c}\text { Indian } \\
\text { Traditional }\end{array}$} & \multicolumn{2}{|c|}{$\begin{array}{c}\text { Western } \\
\text { casual }\end{array}$} & \multicolumn{2}{|c|}{$\begin{array}{l}\text { Western } \\
\text { Formal }\end{array}$} & \multicolumn{2}{|c|}{$\begin{array}{c}\text { Indo- } \\
\text { Western }\end{array}$} & \multicolumn{2}{|c|}{ Total } \\
\hline & & 4 & $16.0 \%$ & 4 & $16.0 \%$ & 12 & $48.0 \%$ & 1 & $4.0 \%$ & 4 & $16.0 \%$ & 25 & $100.0 \%$ \\
\hline & 31-35 & 8 & $32.0 \%$ & 2 & $8.0 \%$ & 9 & $36.0 \%$ & 2 & $8.0 \%$ & 4 & $16.0 \%$ & 25 & $100.0 \%$ \\
\hline & $36-40$ & 3 & $12.0 \%$ & 8 & $32.0 \%$ & 8 & $32.0 \%$ & 2 & $8.0 \%$ & 4 & $16.0 \%$ & 25 & $100.0 \%$ \\
\hline & 41-45 & 13 & $52.0 \%$ & 6 & $24.0 \%$ & 0 & $0.0 \%$ & 1 & $4.0 \%$ & 5 & $20.0 \%$ & 25 & $100.0 \%$ \\
\hline
\end{tabular}


International Journal of Social Science and Economic Research

ISSN: 2455-8834

Volume:05, Issue:08 "August 2020"

\begin{tabular}{|l|l|l|l|l|l|l|l|l|l|l|l|l|} 
Total & 28 & $28.0 \%$ & 20 & $20.0 \%$ & 29 & $29.0 \%$ & 6 & $6.0 \%$ & 17 & $17.0 \%$ & 100 & $100.0 \%$ \\
\hline
\end{tabular}

\begin{tabular}{|l|l|c|}
\hline \multicolumn{2}{c|}{ Pearson Chi-Square Tests } \\
\hline \multicolumn{3}{|c|}{ Style of Clothing Women Prefer to Wear } \\
\hline Age & Chi-square & 24.562 \\
\hline & Df & 12 \\
\hline & Sig. & $.017^{*}$ \\
\hline
\end{tabular}

*Significant at 0.05 Level

\section{Discussion of Result}

Age of Women has a significant influence on the Style of Clothing women prefer to wear. The obtaned value of Chi Square ( $\square 2$ ) is 24.562 which is significant at .017 level of p value.

Table 8: Relationship of Age and Preference for Circular Silhouette in Clothing

\begin{tabular}{|c|c|c|c|c|c|c|c|c|c|c|c|c|c|}
\hline \multirow{3}{*}{$\begin{array}{r}\text { Age } \\
\text { Age }\end{array}$} & \multirow{3}{*}{$\begin{array}{l}\text { Status } \\
25-30\end{array}$} & \multicolumn{12}{|c|}{ Preference for Circular Silhouette in Clothing } \\
\hline & & \multicolumn{2}{|c|}{$\begin{array}{l}\text { Not at all } \\
\text { preferred }\end{array}$} & \multicolumn{2}{|c|}{$\begin{array}{c}\text { Generally } \\
\text { not } \\
\text { preferred }\end{array}$} & \multicolumn{2}{|c|}{ Neutral } & \multicolumn{2}{|c|}{$\begin{array}{c}\text { Preferred } \\
\text { a little }\end{array}$} & \multicolumn{2}{|c|}{$\begin{array}{c}\text { Preferred } \\
\text { the most }\end{array}$} & \multicolumn{2}{|c|}{ Total } \\
\hline & & 3 & $\begin{array}{c}12.0 \\
\%\end{array}$ & 7 & $\begin{array}{c}28.0 \\
\%\end{array}$ & 10 & $\begin{array}{c}40.0 \\
\%\end{array}$ & 4 & $\begin{array}{c}16.0 \\
\%\end{array}$ & 1 & $4.0 \%$ & 25 & $100.0 \%$ \\
\hline & $31-35$ & 1 & $4.0 \%$ & 6 & $\begin{array}{c}24.0 \\
\%\end{array}$ & 16 & $\begin{array}{c}64.0 \\
\%\end{array}$ & 2 & $8.0 \%$ & 0 & $0.0 \%$ & 25 & $100.0 \%$ \\
\hline & $36-40$ & 6 & $\begin{array}{c}24.0 \\
\%\end{array}$ & 9 & $\begin{array}{c}36.0 \\
\%\end{array}$ & 9 & $\begin{array}{c}36.0 \\
\%\end{array}$ & 0 & $0.0 \%$ & 1 & $4.0 \%$ & 25 & $100.0 \%$ \\
\hline & 41-45 & 5 & $\begin{array}{c}20.0 \\
\%\end{array}$ & 4 & $\begin{array}{c}16.0 \\
\%\end{array}$ & 4 & $\begin{array}{c}16.0 \\
\%\end{array}$ & 9 & $\begin{array}{c}36.0 \\
\%\end{array}$ & 3 & $12.0 \%$ & 25 & $100.0 \%$ \\
\hline & Total & \begin{tabular}{|l|}
1 \\
5
\end{tabular} & $\begin{array}{c}15.0 \\
\%\end{array}$ & 26 & $\begin{array}{c}26.0 \\
\%\end{array}$ & 39 & $\begin{array}{c}39.0 \\
\%\end{array}$ & 15 & $\begin{array}{c}15.0 \\
\%\end{array}$ & 5 & $5.0 \%$ & 100 & $100.0 \%$ \\
\hline
\end{tabular}


International Journal of Social Science and Economic Research

ISSN: 2455-8834

Volume:05, Issue:08 "August 2020"

\begin{tabular}{|l|l|c|}
\hline \multicolumn{3}{|c|}{ Pearson Chi-Square Tests } \\
\hline \multicolumn{3}{|c|}{ Preference for Circular Silhouette in Clothing } \\
\hline \multirow{2}{*}{ Age } & Chi-square & 29.128 \\
\cline { 2 - 3 } & df & 12 \\
\cline { 2 - 3 } & Sig. & $.004^{*}$ \\
\hline
\end{tabular}

*Significant at 0.05 Level

\section{Discussion of Result}

Age of Women has significant influence on the preference for Circular Silhouette in Clothing. The obtained value of Chi Square $(\square 2)$ is 29.128 , which is significant at .004 level of p value.

Table 9: Relationship of Age with Preference for A-Line Silhouette in Clothing

\begin{tabular}{|c|c|c|c|c|c|c|c|c|c|c|c|c|c|}
\hline \multirow{3}{*}{$\begin{array}{l}\begin{array}{l}\text { Demographic } \\
\text { Factor }\end{array} \\
\text { Age }\end{array}$} & \multirow{3}{*}{$\begin{array}{c}\begin{array}{c}\text { Age } \\
\text { Groups }\end{array} \\
25-30\end{array}$} & \multicolumn{12}{|c|}{ Preference for A-Line Silhouettes in Clothing } \\
\hline & & \multicolumn{2}{|c|}{$\begin{array}{l}\text { Not at all } \\
\text { preferred }\end{array}$} & \multicolumn{2}{|c|}{$\begin{array}{c}\text { Generally } \\
\text { not } \\
\text { preferred }\end{array}$} & \multicolumn{2}{|c|}{ Neutral } & \multicolumn{2}{|c|}{$\begin{array}{l}\text { Preferred a } \\
\text { little }\end{array}$} & \multicolumn{2}{|c|}{$\begin{array}{c}\text { Preferred } \\
\text { the most }\end{array}$} & \multicolumn{2}{|c|}{ Total } \\
\hline & & 0 & $0.0 \%$ & 0 & $0.0 \%$ & 5 & $20.0 \%$ & 6 & $24.0 \%$ & 14 & $56.0 \%$ & 25 & $100.0 \%$ \\
\hline & $31-35$ & 0 & $0.0 \%$ & 0 & $0.0 \%$ & 9 & $36.0 \%$ & 15 & $60.0 \%$ & 1 & $4.0 \%$ & 25 & $100.0 \%$ \\
\hline & $36-40$ & 0 & $0.0 \%$ & 2 & $8.0 \%$ & 4 & $16.0 \%$ & 5 & $20.0 \%$ & 14 & $56.0 \%$ & 25 & $100.0 \%$ \\
\hline & $41-45$ & 0 & $0.0 \%$ & 1 & $4.0 \%$ & 0 & $0.0 \%$ & 12 & $48.0 \%$ & 12 & $48.0 \%$ & 25 & $100.0 \%$ \\
\hline & Total & 0 & $0.0 \%$ & 3 & $3.0 \%$ & 18 & $18.0 \%$ & 38 & $38.0 \%$ & 41 & $41.0 \%$ & 100 & $100.0 \%$ \\
\hline
\end{tabular}

\section{Pearson Chi-Square Tests}

\begin{tabular}{|l|l|c|}
\hline \multicolumn{2}{|c|}{ Pearson Chi-Square Tests } \\
\hline \multirow{2}{*}{ Preference for A-Line Silhouettes in Clothing } \\
\hline \multirow{2}{*}{ Age } & Chi-square & 31.431 \\
\cline { 2 - 3 } & Df & 9 \\
\cline { 2 - 3 } & Sig. & $.000^{*}$ \\
\hline
\end{tabular}

*Significance at 0.05 Level

\section{Discussion of Result}

Age of Women has a significant influence on the preference for A-Line Silhouettes in Clothing. The obtained value of Chi Square ( $\square 2)$ is 31.431, which is significant at .000 level of $p$ value.

\section{Conclusion}

It is seen that age is the major factor that influences the Choice of Clothing among Women. 
International Journal of Social Science and Economic Research

ISSN: 2455-8834

Volume:05, Issue:08 "August 2020"

Preference for Style and Silhouette of clothing changes with age of women. These findings are supported by the study of Klepp, G et al (2005) "Reading fashion as age: teenage girls, and grown women's accounts of clothing as body and social status" where they found that relationship between clothes and age have always been very important to differentiate people according to age. Mainly people are expected to dress according to their age. If they are found not dressed, accordingly the society imposes sanctions against wearing the costume of another age. Further the findings of Twigg, J (2015) in her study "Clothing, identity, embodiment and age" also highlights the link between clothing and the social expression of age, looking in particular at the tradition of age ordering in dress. There is evidence that this ordering has been eroded or has changed in recent years.

In the present study, as well the research conducted earlier finds that there is a link between age of women and their Choice for Style of Clothing. Age influences Clothing Choices of women. It was further seen that women like to wear what they feel comfortable in.

\section{REFERENCES}

IG, Klepp and AS, Mathisen (2005). "Reading Fashion as Age: Teenage Girls, and grown Women's accounts of Clothing as body and social status". Journal of Fashion Theory, 9(3): 323342.

V.Luniya and B Dwedi (2007). "Effect of Clothing on physical and mental well-being of old aged women". Journal of Asian Journal of Home Science, (2): 39-42.

J. Twigg (2010). "How does Vogue negotiate Age? Fashion, the body and the older women". Journal of Fashion Theory, (14): 471-490.

C, Parveen, A, Khare and A, Mishra (2012). "Influence of collective self-esteem on fashion clothing involvement among Indian Women”. Journal of Fashion Marketing and Management, (16): 42-63.

J, Twigg (2015). "Clothing, Identity, Embodiment and Age”. Journal of Textile-Led Design for the Active Ageing population, 13-24. 